\title{
Celecoxib increases lung cancer cell lysis by lymphokine- activated killer cells via upregulation of ICAM-1
}

\author{
Melina Schellhorn ${ }^{1, *}$, Maria Haustein ${ }^{1, *}$, Marcus Frank ${ }^{2}$, Michael Linnebacher ${ }^{3}$, \\ Burkhard Hinz ${ }^{1}$ \\ ${ }^{1}$ Institute of Toxicology and Pharmacology, Rostock University Medical Center, Rostock, Germany \\ ${ }^{2}$ Electron Microscopy Center, Rostock University Medical Center, Rostock, Germany \\ ${ }^{3}$ Section of Molecular Oncology and Immunotherapy, Department of General Surgery, Rostock University Medical Center, \\ Rostock, Germany \\ * These authors have contributed equally to this work \\ Correspondence to: \\ Burkhard Hinz, e-mail: burkhard.hinz@med.uni-rostock.de \\ Keywords: celecoxib, intercellular adhesion molecule 1, lung cancer cells, immune surveillance, lymphokine-activated
} killer cells

Received: July 06, 2015

Accepted: October 09, 2015

Published: October 22, 2015

\section{ABSTRACT}

The antitumorigenic mechanism of the selective cyclooxygenase-2 (COX-2) inhibitor celecoxib is still a matter of debate. Using lung cancer cell lines (A549, H460) and metastatic cells derived from a lung cancer patient, the present study investigates the impact of celecoxib on the expression of intercellular adhesion molecule 1 (ICAM-1) and cancer cell lysis by lymphokine-activated killer (LAK) cells. Celecoxib, but not other structurally related selective COX-2 inhibitors (i.e., etoricoxib, rofecoxib, valdecoxib), was found to cause a substantial upregulation of ICAM-1 protein levels. Likewise, ICAM-1 mRNA expression was increased by celecoxib. Celecoxib enhanced the susceptibility of cancer cells to be lysed by LAK cells with the respective effect being reversed by a neutralizing ICAM-1 antibody. In addition, enhanced killing of celecoxib-treated cancer cells was reversed by preincubation of LAK cells with an antibody to lymphocyte function associated antigen 1 (LFA-1), suggesting intercellular ICAM-1/LFA-1 crosslink as crucial event within this process. Finally, celecoxib elicited no significant increase of LAK cellmediated lysis of non-tumor bronchial epithelial cells, BEAS-2B, associated with a far less ICAM-1 induction as compared to cancer cells. Altogether, our data demonstrate celecoxib-induced upregulation of ICAM-1 on lung cancer cells to be responsible for intercellular ICAM-1/LFA-1 crosslink that confers increased cancer cell lysis by LAK cells. These findings provide proof for a novel antitumorigenic mechanism of celecoxib.

\section{INTRODUCTION}

Celecoxib is a selective inhibitor of the prostaglandin (PG)-synthesizing enzyme cyclooxygenase-2 (COX-2) [1]. Owing to its analgesic and anti-inflammatory effects, the selective COX-2 inhibitor (coxib) was approved for the symptomatic treatment of pain associated with rheumatoid arthritis and arthrosis in 1998. In addition, a 6-months treatment with a daily dose of $800 \mathrm{mg}$ celecoxib was demonstrated to result in significant reductions of colorectal polyps in patients with familial adenomatous polyposis (FAP) [2], resulting in celecoxib's approval for adjuvant treatment of FAP patients by the US Food and Drug Administration in 1999. In matter of lung cancer reports have suggested celecoxib as treatment and preventive option [3-6] and to enhance the response to preoperative paclitaxel and carboplatin in early-stage non-small cell lung cancer (NSCLC) [7]. Taken into account that lung cancer is worldwide the most common cancer in terms of both incidence and mortality and that the response and remission rates in NSCLC patients still remain relatively low [8], these findings may offer new pharmacotherapeutical options in this field.

On the cellular level celecoxib exerts its anticarcinogenic action primarily via induction of cancer cell apoptosis or inhibition of proliferation (for review 
see [9]). Increasing evidence suggests a significant part of this action to occur independent of celecoxib's COX-2 inhibitory activity [9-13]. In a recent study, celecoxib was shown to even enhance COX-2 expression and PG formation by lung cancer cells as key events within its proapoptotic action [14]. However, the impact of celecoxib on cancer cell lysis resulting from tumor-immune interactions has been poorly investigated. In one study, celecoxib was found to produce a downregulation of major histocompatibility complex I molecule expression on metastatic breast cancer cells, thereby leading to improved recognition by natural killer (NK) cells conferring an enhanced tumor cell lysis [15].

The intercellular adhesion molecule 1 (ICAM-1), a glycoprotein consisting of five extracellular immunoglobulin-like domains, a transmembrane and a C-terminal intracellular domain [16], plays an important role in tumor immune surveillance and elimination of neoplastic cells [17]. There are several studies indicating cytokineinduced upregulation of ICAM-1 on cancer cells [18-23] or cancer cell transfection with the ICAM-1 gene [24, 25] to confer increased cytotoxic tumor cell lysis by immune cells. In the same context, a recent in vitro study suggests ICAM-1 upregulation as part of pharmacotherapeutic strategies. Accordingly, cannabinoids, a group of substances with diverse anticarcinogenic properties, have been shown to enhance the susceptibility of lung cancer cells to cytolytic death mediated by lymphokine-activated killer (LAK) cells via increase of ICAM-1 on cancer cell surface [26]. In line with its antitumorigenic responses observed in vitro, ICAM-1 expression has been likewise reported to be negatively correlated with metastasis of several cancer types in clinical studies [27-29].

The present study investigates the impact of celecoxib on tumor immune surveillance and the role of ICAM-1 within this process. Here we show that celecoxib, but not other structurally related COX-2 inhibitors, induces an upregulation of ICAM-1 expression on lung cancer cells, thereby causing increased cancer cell lysis by LAK cells. These findings provide evidence for a hitherto unknown mechanism underlying the anticarcinogenic action of celecoxib.

\section{RESULTS}

\section{Celecoxib induces ICAM-1 expression on both protein and mRNA level}

To investigate the impact of celecoxib on ICAM-1 expression and tumor cell lysis two human NSCLC cell lines (A549, H460) as well as metastatic cells derived from a lung cancer patient were used. In each of these cell types celecoxib was found to stimulate the protein expression of ICAM-1 (Fig. 1A-1C). According to an all-or-none principle this effect was significant after a treatment with $30 \mu \mathrm{M}$ celecoxib in all three cell lines.
Additional experiments were performed to investigate the impact of three other structurally similar selective COX-2 inhibitors (etoricoxib, rofecoxib, valdecoxib) on ICAM-1 protein expression (Fig. 1D-1F). In fact, an upregulation of ICAM-1 protein greater than 3-fold was unique for celecoxib and was not shared by other selective COX-2 inhibitors. These findings are consistent with recently published data by our group indicating an upregulation of COX-2 expression by celecoxib, but not by other COX-2 inhibitors [14].

Time-course experiments revealed a significant upregulation of ICAM-1 protein expression in lung cancer cells after a 48-h incubation with $30 \mu \mathrm{M}$ celecoxib (Fig. 2A-2C). In accordance to elevated protein levels an increase of ICAM-1 mRNA level was detected after $6 \mathrm{~h}$ in each cell line (Fig. 2D-2F).

\section{Celecoxib increases LAK cell-mediated tumor cell lysis}

To investigate the functional consequence of increased ICAM-1 expression by celecoxib, LAK cellmediated tumor cell killing was investigated using a co-culture of LAK cells and pretreated cancer cells at a defined effector:target cell ratio (see Materials and Methods). Noteworthy, lymphocyte function associated antigen 1 (LFA-1), the cognate ICAM-1 receptor on the surface of immune cells, has recently been demonstrated to confer LAK cell-mediated killing of lung cancer cells incubated with the ICAM-1-upregulating phytocannabinoid cannabidiol before [26].

The close interactions between tumor cells and LAK cells were visualized by scanning electron microscopy showing a firm attachment of the LAK cell with their processes to the tumor cell surface (Fig. 3A, upper two panels). The identity of LAK cells was verified by immuno-labelling using an LFA-1 antibody in conjunction with a secondary antibody coupled to $15 \mathrm{~nm}$ colloidal gold, detectable as bright dots by high resolution electron microscopy (Fig. 3A, lower two panels with inserts). The scanning electron microscopy analysis shows that gold grains indicating LFA-1 expression decorate the cell surface and processes of LAK cells (e.g., lowermost panel, open arrows), whereas the cell bodies and filopodial extensions of the underlying tumor cells are devoid of LFA-1 labelling (lowermost panel, filled arrows).

To address the impact of celecoxib on LAK cellmediated tumor cell lysis, tumor cells that were incubated with increasing concentrations of celecoxib for $48 \mathrm{~h}$ were subsequently labeled with calcein-AM and co-cultured with LAK cells. Following a 6 -h incubation, tumor cell lysis was measured by detection of calcein fluorescence in the supernatant. As shown in Fig. 3B-3D, celecoxib at $30 \mu \mathrm{M}$ increased LAK cell-mediated tumor cell lysis of each tested lung cancer cell line. In some cases lysis of cancer cells appeared to be higher in the absence of LAK cells resulting in negative values of calculated percental 
A

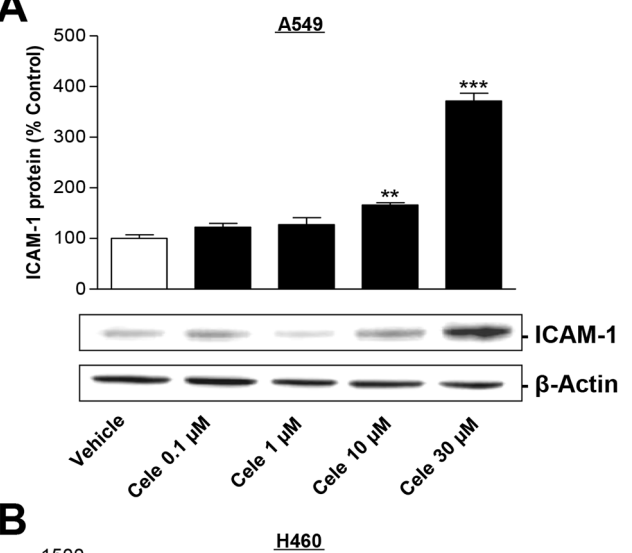

B

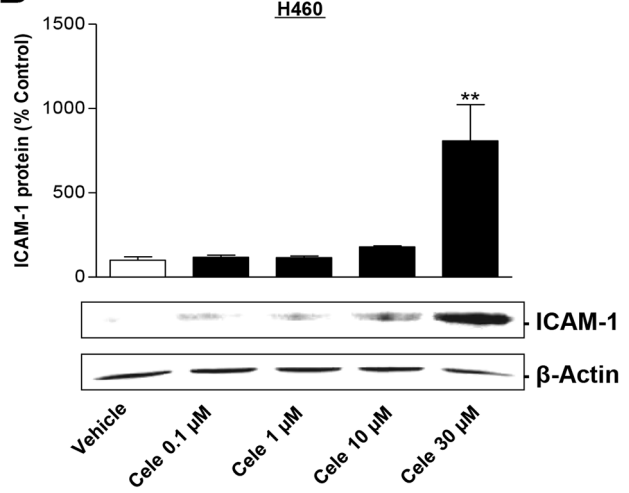

C

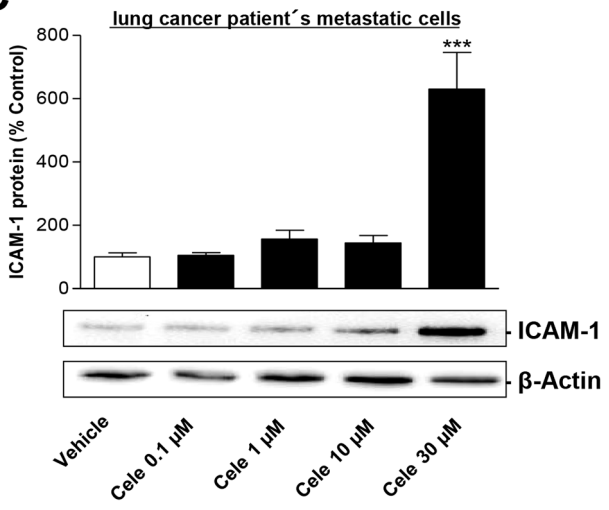

D

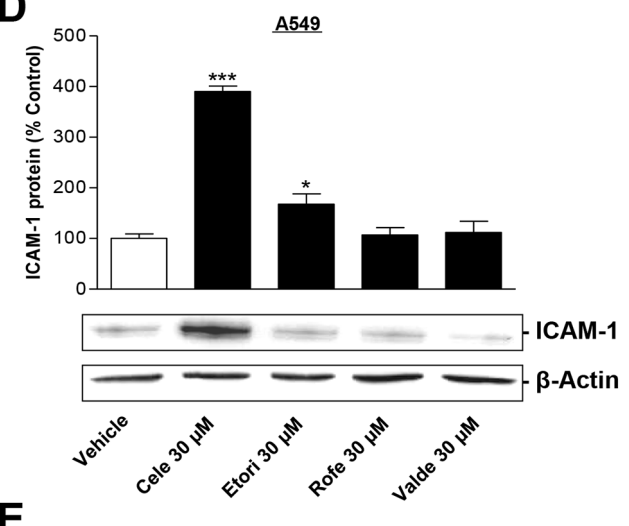

E

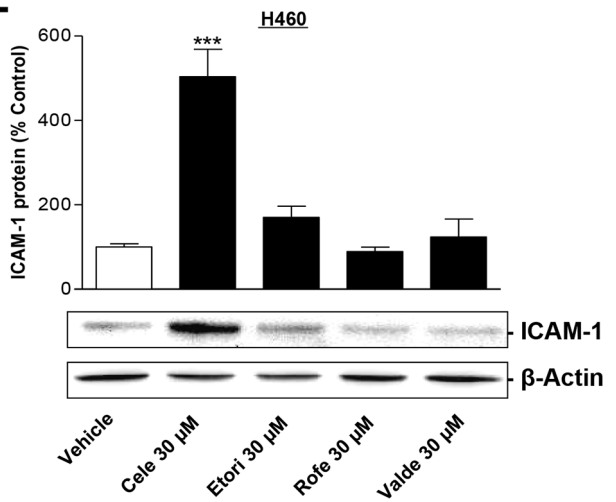

$\mathbf{F}$

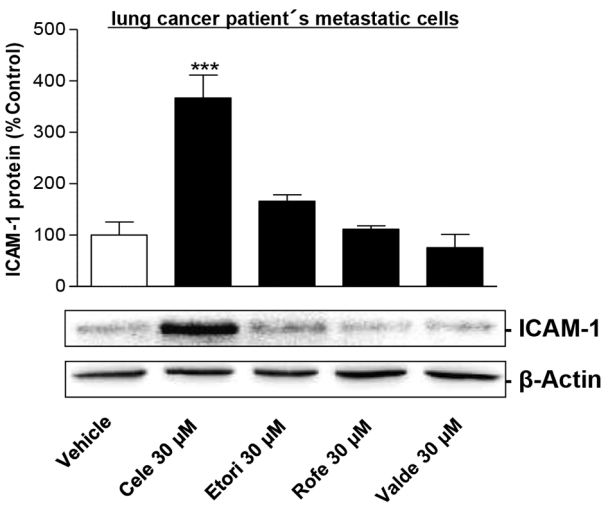

Figure 1: Effect of celecoxib and other selective COX-2 inhibitors on ICAM-1 protein expression in human lung cancer cells. Left panels: Concentration-dependent impact of celecoxib on ICAM-1 protein expression in A549 A. H460 B. and lung cancer patient's metastatic cells $\mathbf{C}$. Cells were incubated with celecoxib at the indicated concentrations for $48 \mathrm{~h}$. Histograms above selected blots represent means \pm SEM obtained from densitometric analysis of $n=4(\mathrm{~A}, \mathrm{C})$ or $n=3$ (B) blots. Right panels: Influence of selective COX-2 inhibitors on ICAM-1 protein expression in A549 D. H460 E. and lung cancer patient's metastatic cells F. Tumor cells were treated with $30 \mu \mathrm{M}$ celecoxib (Cele), etoricoxib (Etori), rofecoxib (Rofe), valdecoxib (Valde) or vehicle for $48 \mathrm{~h}$. Histograms above selected blots represent means \pm SEM obtained from densitometric analysis of $n=4$ (D, E, F) blots. ${ }^{*} P<0.05,{ }^{* *} P<0.01, * * * P<0.001$; one-way ANOVA plus post hoc Dunnett test.

LAK cytotoxicities, which is in line with observations from other groups $[23,30]$.

Recently, our group reported a toxic effect of celecoxib on lung tumor cells [14]. Thus, viability tests were performed. As compared to vehicle (100\% viability), incubation of tumor cells with $30 \mu \mathrm{M}$ celecoxib yielded viability rates of $64 \% \pm 8 \%$ for $\mathrm{A} 549,49 \% \pm 3 \%$ for $\mathrm{H} 460$ and $45 \% \pm 4 \%$ for lung cancer patient's metastatic cells (all values as means \pm SEM of $n=20-25$ experiments).

\section{Celecoxib does not interfere with LAK cell function}

Further experiments were performed to address the impact of celecoxib on tumor cell lysis under conditions where LAK cells are exposed to this compound as would be the case under in vivo conditions. To this end, LAK cells prepared and cultured using the same protocol were additionally incubated with celecoxib or 
A

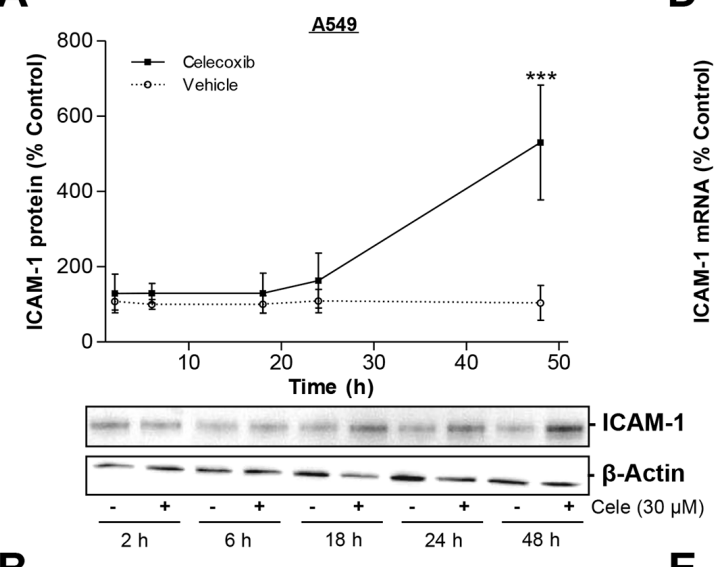

B

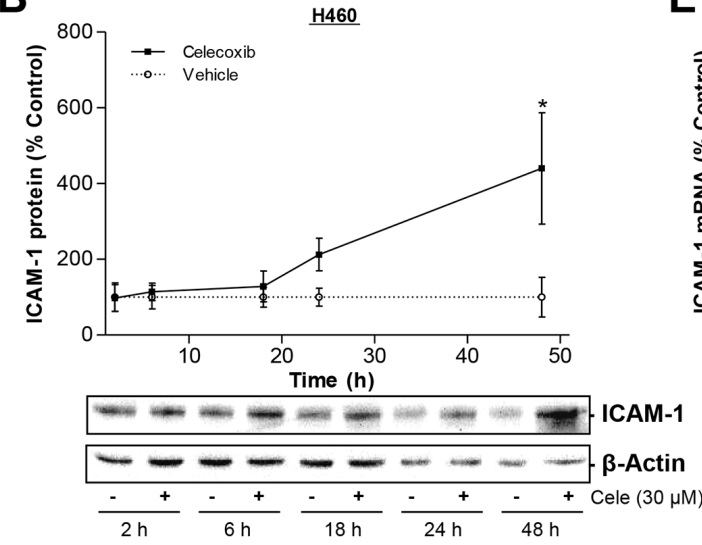

$\mathrm{c}$

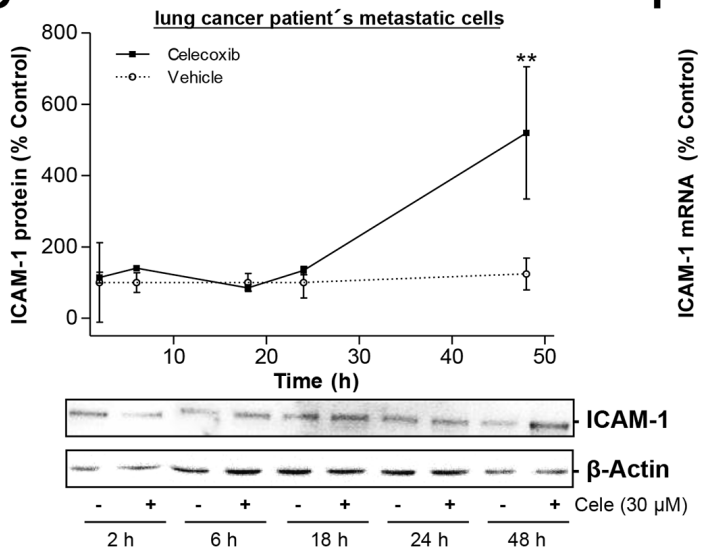

D

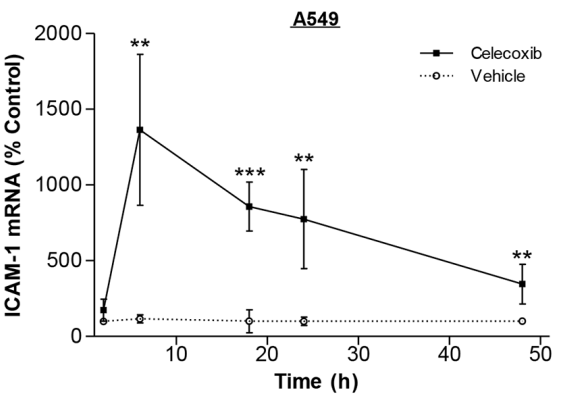

E

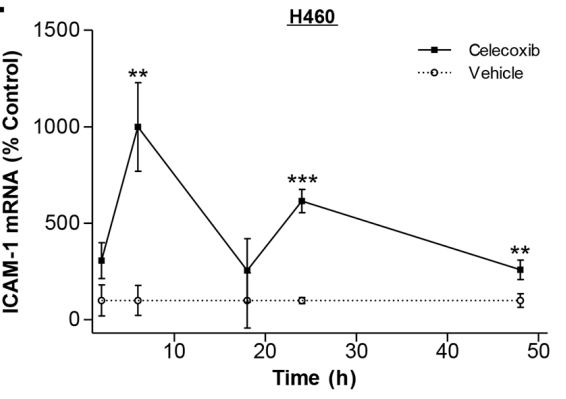

F

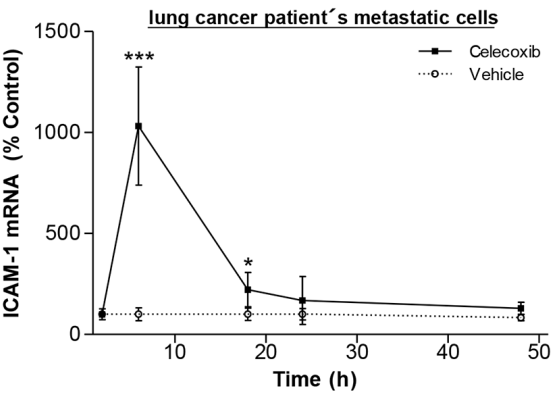

Figure 2: Time-dependent impact of celecoxib on ICAM-1 expression in A549, H460 and lung cancer patient's metastatic cells. A-C. Western blot analysis of celecoxib's $(30 \mu \mathrm{M})$ effect on ICAM-1 protein expression over a 48-h incubation period. Values are means \pm SEM obtained from densitometric analysis of $n=3$ blots. ${ }^{*} P<0.05, * * P<0.01, * * * P<0.001$ vs. corresponding vehicle control of the respective ICAM-1 analysis; Student's $t$ test. D-F. Real-time RT-PCR analysis of the impact of $30 \mu \mathrm{M}$ celecoxib on ICAM-1 mRNA expression over a 48-h incubation period. Values are means \pm SEM of $n=4$ experiments. ${ }^{*} P<0.05,{ }^{* *} P<0.01, * * * P<0.001$ vs. corresponding vehicle control of the respective ICAM-1 analysis; Student's $t$ test.

vehicle control for $48 \mathrm{~h}$. However, the results obtained from these experiments (Fig. 4A-4C) revealed no influence of a pretreatment of LAK cells with celecoxib on LAK cell-mediated tumor cell lysis, implying the cytotoxic activity of LAK cells to be unaltered by celecoxib.

\section{ICAM-1 antibody suppresses celecoxib-induced LAK cell-mediated tumor cell lysis}

To confirm a causal link between celecoxib-induced upregulation of ICAM-1 protein expression and the concomitant increase of LAK cell-mediated tumor cell 
A
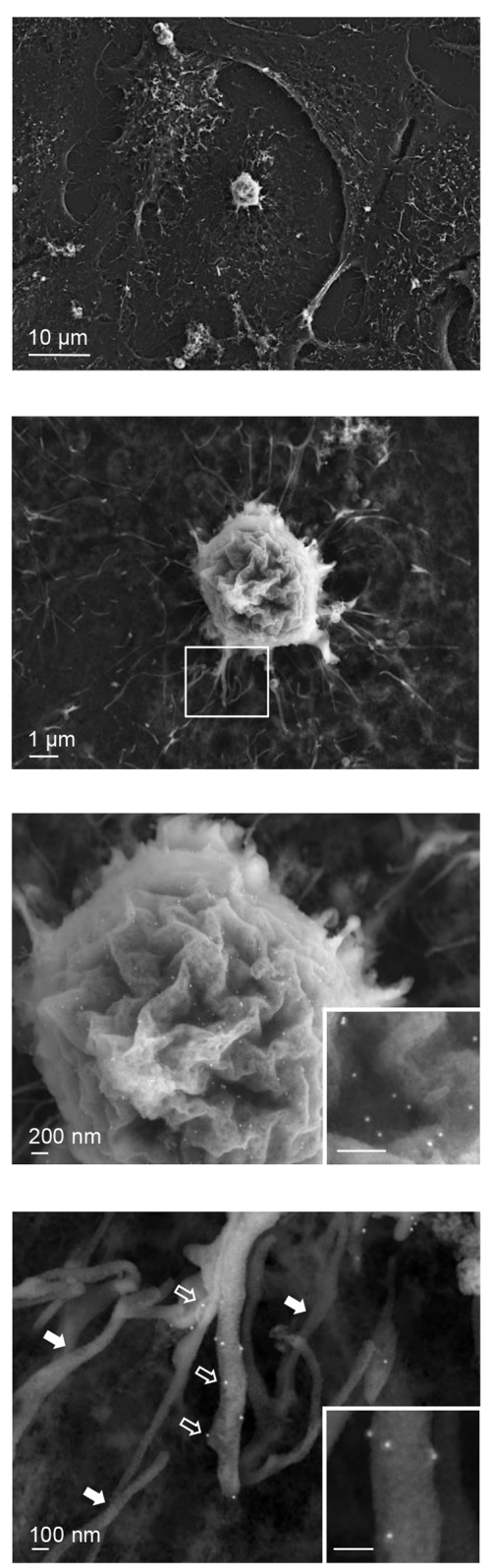

B

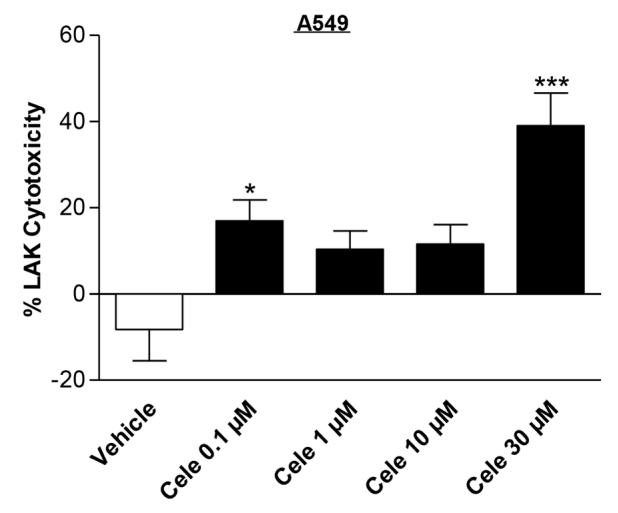

C

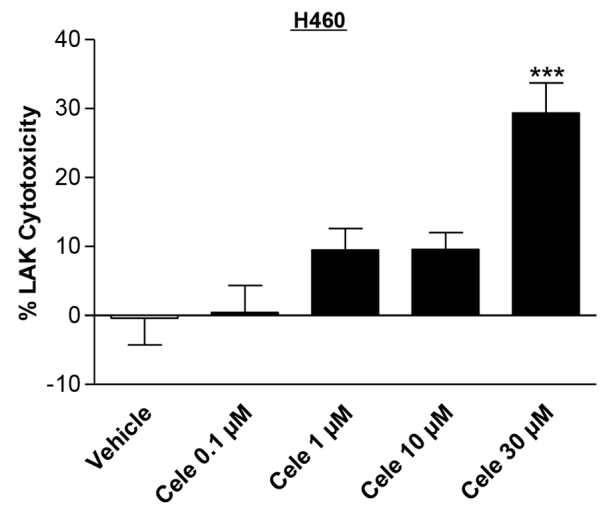

D

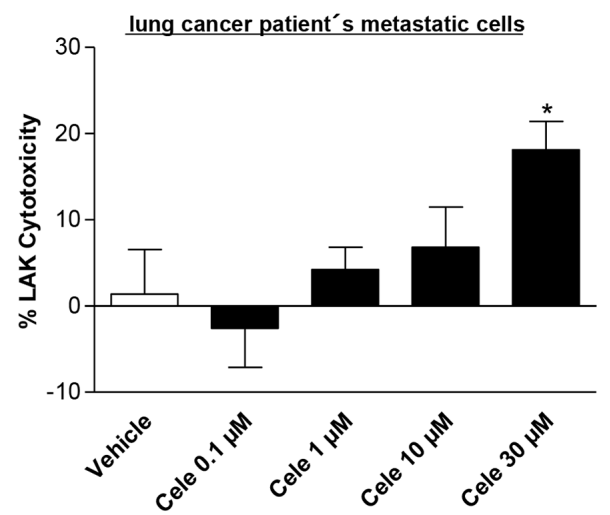

Figure 3: Effect of celecoxib on LAK cell-mediated tumor cell killing. A series of scanning electron micrographs (A. left panels) visualizes the interactions between LAK cells and tumor cells. Electron micrographs at lower magnification show that LAK cells firmly attach to the spread A549 tumor cells with their processes (upper two panels). In addition, immunolabelling with LFA-1 antibody and a secondary antibody coupled to $15 \mathrm{~nm}$ colloidal gold was used to mark LAK cells. The gold labelling is visible as bright dots in the electron micrographs at higher magnifications (lower two panels with inserts) and decorates the cell body (second to last panel) as well as the processes of the LAK cell (lowermost panel, corresponding to the boxed area in the low magnification second from above panel). Note that the $15 \mathrm{~nm}$ gold labeling is confined to the processes of the LAK cell (open arrows) but is absent from the intermingled filopodia of the underlying tumor cell (filled arrows). Right panels: Concentration-dependent impact of celecoxib on LAK cell-mediated killing of A549 B. H460 C. or lung cancer patient's metastatic cells D. Tumor cells were incubated with celecoxib at the indicated concentrations for $48 \mathrm{~h}$. Subsequently, these cells were co-incubated with LAK cells for $6 \mathrm{~h}$. Values are means \pm SEM of $n=24$ (B, 6 donors), $n=28$ (C, 7 donors) or $n=20$ (D, 5 donors) experiments. $* P<0.05,{ }^{* * *} P<0.001$ vs. corresponding vehicle control; one-way ANOVA plus post hoc Dunnett test.

lysis by celecoxib, a neutralizing antibody to ICAM-1 was tested for its inhibitory action on tumor cell lysis. In all tumor cells investigated the ICAM-1 antibody significantly suppressed the celecoxib-induced tumor cell lysis by LAK cells when compared to cells treated with vehicle and isotype control antibody, respectively (Fig. 5A-5C). Noteworthy, both neutralizing ICAM-1 antibody and isotype control antibody did not alter the celecoxib-induced loss of cancer cell viability as assessed by WST-1 analysis (data not shown). 
A
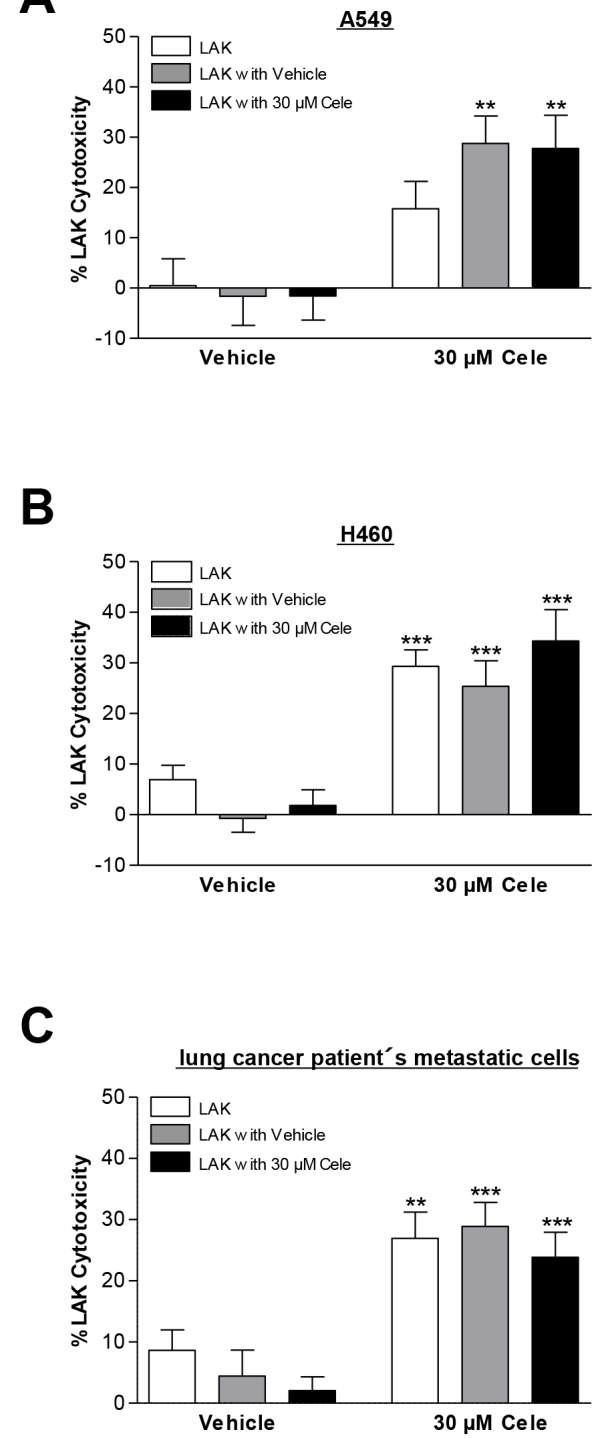

Figure 4: Impact of celecoxib on cytotoxic activity of LAK cells. The respective subgroups indicate lysis of cancer cells when LAK cells were preincubated for $48 \mathrm{~h}$ in medium (white bars), medium containing vehicle (grey bars) or $30 \mu \mathrm{M}$ celecoxib (black bars) prior to co-culturing with cancer cells. As LAK cell medium RPMI 1640 supplemented with $10 \%$ heat-inactivated FCS, $100 \mathrm{U} / \mathrm{ml}$ penicillin, $100 \mathrm{\mu g} / \mathrm{ml}$ streptomycin and $10 \mathrm{ng} / \mathrm{ml} \mathrm{IL-2} \mathrm{was} \mathrm{used.} \mathrm{Cytotoxicity} \mathrm{was} \mathrm{analyzed} \mathrm{following} \mathrm{a} \mathrm{subsequent} \mathrm{6-h} \mathrm{co-incubation} \mathrm{of} \mathrm{LAK} \mathrm{cells}$ with cancer cells. Values are means \pm SEM of $n=12$ (A. 3 donors), $n=20$ (B. 5 donors) or $n=16$ (C. 4 donors) experiments. $* * P<0.01$, ${ }^{* * *} P<0.001$ vs. corresponding vehicle control; Student's $t$ test.

\section{LFA-1 antibody reverses celecoxib-induced tumor cell killing by LAK cells}

The interaction of tumor and LAK cells is shown by light microscopy in Fig. 6A. According to immunocytochemical analysis (Fig. 6B), CD11a (LFA-1) is present on the surface of LAK cells (Fig. 6B, green fluorescence), but not detectable on the surface of tumor cells.

To verify an intercellular ICAM-1/LFA-1 crosslink as crucial event within the process of LAK cell-mediated lysis of celecoxib-treated tumor cells, LAK cells were preincubated with a neutralizing LFA-1 antibody for
$2 \mathrm{~h}$ before killing assay was started. According to the histograms presented in Fig. 6C-6E, the neutralizing LFA-1 antibody significantly inhibited the effect of LAK cell-mediated tumor cell lysis by celecoxib. These results indicate LFA-1 as a potential receptor for ICAM-1 conferring LAK cell-mediated tumor cell lysis.

\section{Celecoxib does not affect human bronchial epithelial cells}

To evaluate if celecoxib has any effect on nontumor cells, the bronchial epithelial cell line BEAS-2B was used in further experiments. As shown in Fig. 7A, 
A

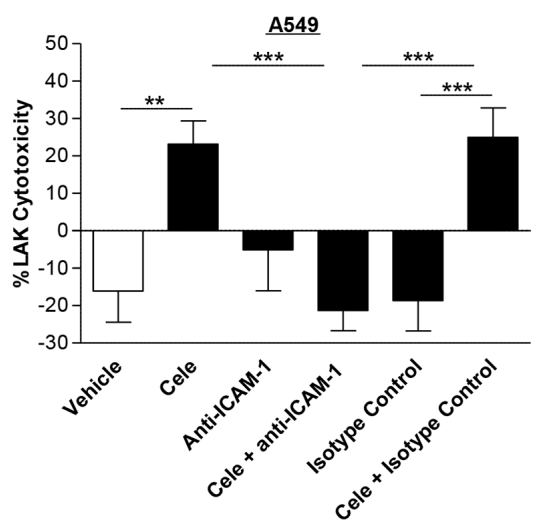

B

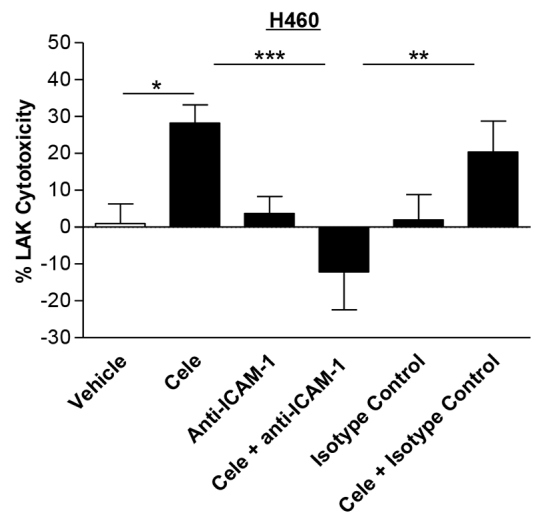

C

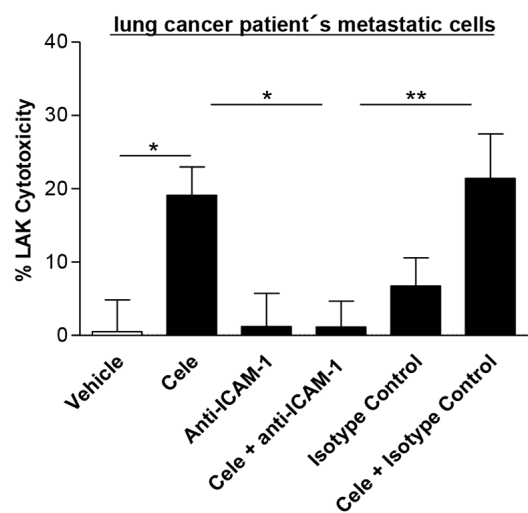

Figure 5: Effect of a neutralizing ICAM-1 antibody on cytotoxic lysis of cancer cells by LAK cells. A549 A. H460 B. and lung cancer patient's metastatic cells $\mathbf{C}$. were incubated with vehicle or $30 \mu \mathrm{M}$ celecoxib for $48 \mathrm{~h}$. Before starting cytotoxicity assay cancer cells were pre-incubated with an ICAM-1 antibody $(1 \mu \mathrm{g} / \mathrm{ml})$ for $2 \mathrm{~h}$. An isotype control antibody $(1 \mu \mathrm{g} / \mathrm{ml})$ was used as negative control. Values are means \pm SEM of $n=24$ (A, 6 donors), $n=16$ (B, 4 donors) or $n=20$ (C, 5 donors) experiments. $* P<0.05$, ${ }^{*} P<0.01$, $* * * P<0.001$; one-way ANOVA plus post hoc Bonferroni test.

celecoxib did not cause a significant upregulation of ICAM-1 protein expression in BEAS-2B cells. In comparison, the same concentration of celecoxib tested under comparable experimental conditions resulted in an upregulation of ICAM-1 protein level in lung cancer cells (A549, H460, lung cancer patient's metastatic cells) by up to 3.7- (Fig. 1A), 8- (Fig. 1B) or 6.3-fold (Fig. 1C) over control. Additional experiments disproved an increase of LAK cell-mediated lysis of
BEAS-2B cells treated with various concentrations of celecoxib for $48 \mathrm{~h}$ (Fig. 7B).

\section{DISCUSSION}

The present study provides first-time proof for celecoxib to induce upregulation of the adhesion molecule ICAM-1 on the surface of tumor cells, resulting in increased tumor cell lysis by LAK cells. 
A
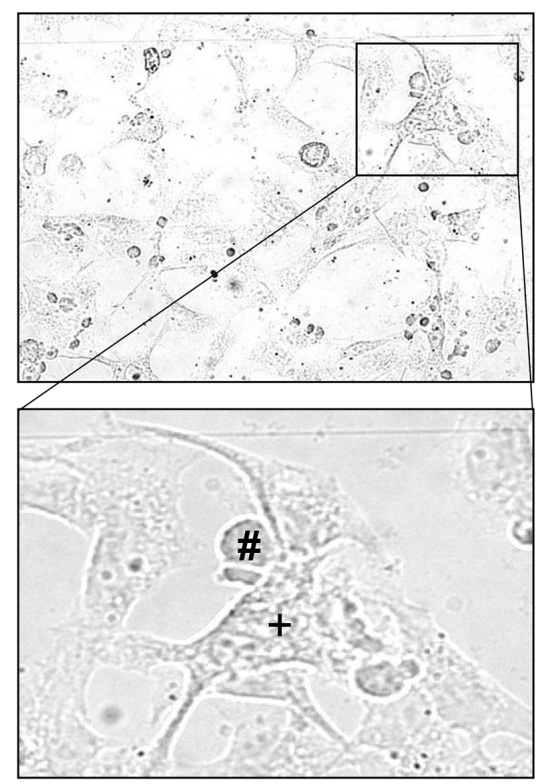

B
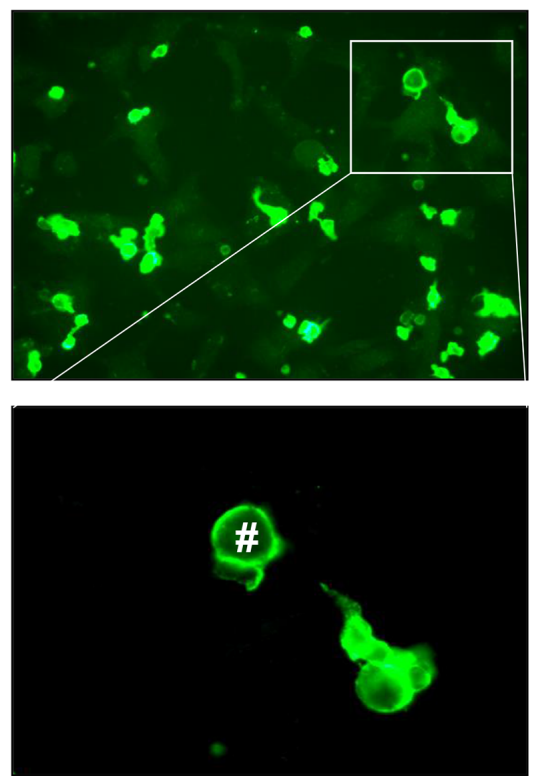

C

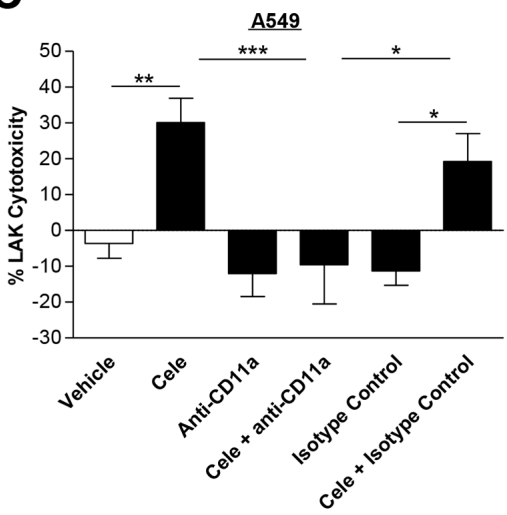

D

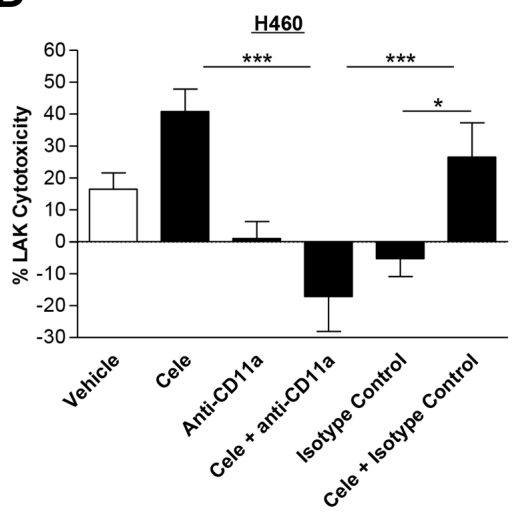

$\mathbf{E}$

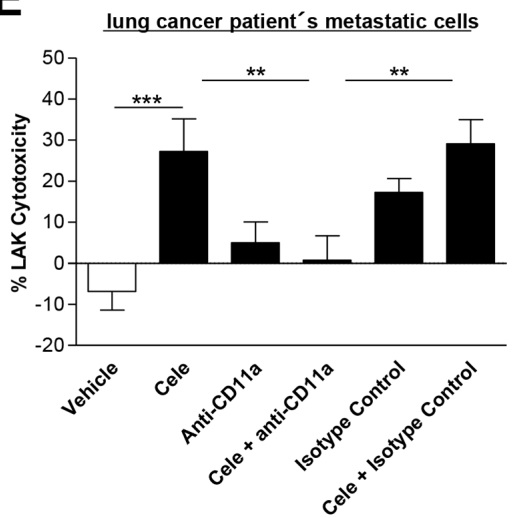

Figure 6: Effect of a CD11a (LFA-1) neutralizing antibody on interaction of cancer cells with LAK cells. Light microscopy picture A. presents interaction between tumor $(+)$ and LAK cells $(\#)$, whereas fluorescence microscopy pictures show immunocytochemical staining of LFA-1 expression on the surface of the immune cells (B. green fluorescence). Right panels: Influence of CD11a (LFA-1) antibody on cytotoxic lysis of cancer cells by LAK cells. A549 C. H460 D. and lung cancer patient's metastatic cells E. were incubated with vehicle or $30 \mu \mathrm{M}$ celecoxib for $48 \mathrm{~h}$. LAK cells were pre-incubated with a CD11a antibody ( $1 \mu \mathrm{g} / \mathrm{ml})$ or an isotype control antibody $(1 \mu \mathrm{g} / \mathrm{ml})$ as negative control for $2 \mathrm{~h}$ before cytotoxicity assay was started. Values are means \pm SEM of $n=20$ (C, D, 5 donors) or $n=28$ (E, 7 donors) experiments. $* P<0.05, * * P<0.01, * * * P<0.001$; one-way ANOVA plus post hoc Bonferroni test.

There are several lines of evidence supporting this notion. First, celecoxib caused a substantial upregulation of ICAM-1 expression on both mRNA and protein level in lung tumor cell lines as well as in metastatic lung cancer cells. Second, celecoxib treatment of lung cancer cells resulted in an enhanced susceptibility to cytotoxic lysis by LAK cells. Third, the celecoxib-induced increase of LAK cell-mediated lysis of tumor cells was abrogated by neutralizing antibodies against ICAM-1 and LFA-1. The LFA-1 heterodimer (CD11a/CD18) is the natural ligand of ICAM-1 [31] that has been reported to represent an important link to conjugate ICAM-1-bearing cells with natural killer cells [32] and to confer lymphocyte-induced tumor cell killing [33]. The data presented here suggest LFA-1 as a crucial counter-receptor 


\section{A}
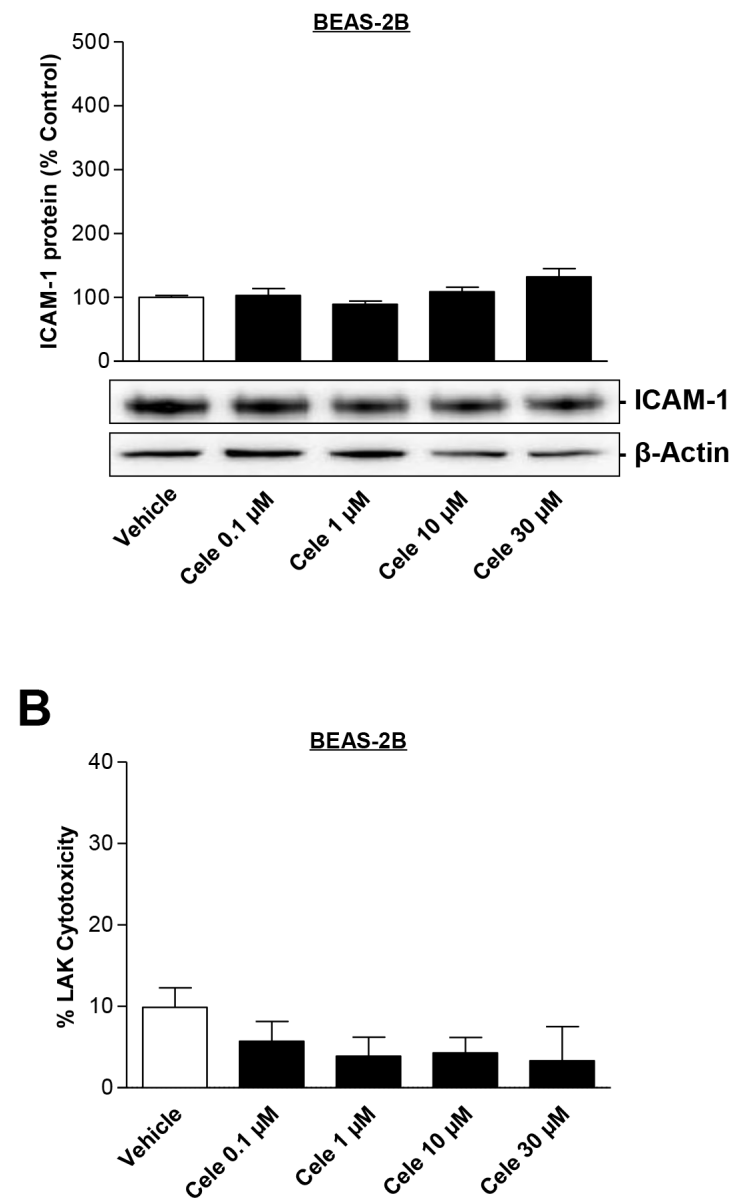

Figure 7: Concentration-dependent effect of celecoxib on ICAM-1 protein expression in human bronchial epithelial cells (BEAS-2B) and on cytotoxic lysis of BEAS-2B cells by LAK cells. BEAS-2B cells were incubated with celecoxib at the indicated concentrations for $48 \mathrm{~h}$. Histogram A. above the selected blot represents means \pm SEM obtained from densitometric analysis of $n=5$ blots. Values in B. are means \pm SEM of $n=20$ ( 5 donors) experiments. One-way ANOVA plus post hoc Dunnett test revealed no significant effect of celecoxib vs. vehicle.

of ICAM-1 in conferring the celecoxib-induced enhanced susceptibility of lung cancer cells to LAK cell-mediated killing. Fourth, tumor cells were lysed by celecoxib-treated LAK cells to a comparable extent as by untreated or vehicletreated LAK cells, thereby confirming celecoxib to enhance the susceptibility of tumor cells to LAK cell-induced killing while sparing direct effects on LAK cell activity. Overall, this data are in good line with several studies indicating enhanced ICAM-1 expression to confer an increased lysis of cancer cells by immune cells comprising NK and LAK cells, monocytes and tumor-infiltrating lymphocytes [18-26].

In the present study upregulation of ICAM-1 protein expression in lung cancer cells was confined to celecoxib and was not elicited by other related selective COX-2 inhibitors (i. e., etoricoxib, rofecoxib, valdecoxib) bearing a diaryl heterocyclic structure. This pattern is in agreement with a recent study from our group that shows a specificity of celecoxib among other selective COX-2 inhibitors in inducing lung cancer cell apoptosis and upregulating COX-2 expression [14]. Likewise, celecoxib, but not other selective COX-2 inhibitors, has been reported to induce apoptosis in synovial fibroblasts [34] and to cause antiproliferative effects on colon cancer cells and reduction of tumor growth in vivo [35].

Clearly, the concentrations of celecoxib causing ICAM-1 expression (i.e., $30 \mu \mathrm{M}$ ) or apoptosis in other studies (i.e., 40-100 $\mu \mathrm{M}$ ) [9] exceed plasma concentrations of celecoxib, which have been reported to reach a maximum of $7.67 \mu \mathrm{M}$ after single-dose administration of $800 \mathrm{mg}$ celecoxib to human volunteers [1]. However, the unique effects of celecoxib within the coxibs may be due to an intracellular accumulation of this COX-2 inhibitor. Accordingly, celecoxib was detected at five- to ten-fold higher intracellular concentrations in different tumor cell types when compared to other coxibs (etoricoxib, lumiracoxib, rofecoxib, valdecoxib) [36]. According to Maier et al. [36] the intracellular 
accumulation of celecoxib results from integration into cellular phospholipid membranes and may thus provide a molecular basis for celecoxib's ability to interact with non-COX-2 targets in vivo despite comparatively low plasma concentrations [36]. For example, celecoxib at $50 \mu \mathrm{M}$ has been reported to cause a COX-2-independent activation of the transcription factor nuclear factor $\kappa \mathrm{B}$ $[37,38]$ that plays a pivotal role in ICAM-1 expression [39]. In addition, higher intracellular concentrations may be achieved in vivo through longer exposure times. Accordingly, cancer patients receive repeated treatment over weeks or months resulting in cumulative effects of the respective chemotherapy or radiation therapy $[9,40]$.

Upregulation of ICAM-1 is likewise supposed to mediate several adverse effects such as perpetuation of bronchial injury by adhesion of neutrophils to epithelial cells [41]. Consequently, the impact of celecoxib on healthy tissue was evaluated by use of the bronchial epithelial cell line BEAS-2B, which was established from normal bronchial epithelium of non-cancerous individuals [42]. However, in contrast to lung cancer cells celecoxib neither significantly affected ICAM-1 protein expression nor susceptibility of these cells against LAK cell-induced cytotoxicity. In line with this finding celecoxib was previously reported to impair the growth of colorectal cancer in vivo without causing toxic effects on normal gut epithelium [43].

In matter of ICAM-1 expression some studies indicate an inhibition of protein expression by celecoxib. Thus, celecoxib was shown to cause inhibition of ICAM-1 expression in colon cancer cells and a decreased adhesion to fetal calf serum (FCS)-coated plastic wells with both events mediated via a COX-2-independent pathway [44]. However, the maximal inhibitory effect of celecoxib $(10 \mu \mathrm{M})$ on ICAM-1 expression occurred after a 4-h incubation with a maximal decrease of about $45 \%$ and already declined after $6 \mathrm{~h}$ [44]. In another investigation the same group found a 4-h incubation of tumor necrosis factor $\alpha$-stimulated human umbilical vein endothelial cells with celecoxib to decrease ICAM-1 and vascular cell adhesion molecule 1 expression with a maximal inhibition of about $60 \%$ and $50 \%$ at $10 \mu \mathrm{M}$ celecoxib, respectively, followed by reduced adhesion of colon cancer cells to endothelial cells [45]. Further studies indicate that celecoxib treatment of mice with experimentally induced atherosclerosis [46] and autoimmune encephalomyelitis [47] or rats with colitis and lung injury [48, 49] decreases the expression of ICAM-1. The reasons for this apparent discrepancy remain to be identified but may be explained, in case of in vitro studies, by the different experimental settings and specificity of cell types, respectively.

Altogether, the results of this study argue for an antitumorigenic function of ICAM-1. This view is further corroborated by animal studies that determined a 2.6-fold greater tumor volume in ICAM-1-deficient mice than in wild-type mice 14 days after injection of melanoma cells [50] or a development of malignant tumors in LFA-1-deficient but not wild-type mice injected with cancer cells [51]. In athymic nude mice the non-psychoactive cannabidiol elicited an increase of ICAM-1 protein in A549 xenografts and an antimetastatic effect that was fully reversed by a neutralizing antibody against ICAM-1 [52]. In other murine models ICAM-1 overexpression on tumor cells was found to elicit a reduced tumor growth $[25,53]$. Analyses of primary tumors from patients with breast cancer revealed a negative correlation of ICAM-1 expression to tumor size, lymph node metastasis and tumor infiltration as well as a better relapsefree and overall survival in patients with ICAM-1-positive tumors than in those with negative tumors [27]. In line with this notion, the incidence of lymph node or liver metastasis was significantly lower in patients with ICAM-1-positive colorectal tumors than in those with ICAM-1-negative tumors [29]. Infiltration of tumor infiltrating lymphocytes was more frequently observed in the ICAM-1-positive tumors in this study [29]. In patients with gastric cancer ICAM-1 expression on cancer cells was significantly decreased in patients with lymph node metastasis with the prognosis of patients being poorer in patients with ICAM-1-negative tumors [28]. Other studies showed an association between ICAM-1 expression and infiltration of lymphocytes into tumor tissue of patients with renal cell carcinoma [54], colorectal [55] and esophageal cancer [56].

Collectively, the present study identified upregulation of ICAM-1 expression in lung cancer cells leading to LAK cell-mediated tumor cell lysis as a novel antitumorigenic mechanism of celecoxib. Further studies addressing the impact of celecoxib on tumor immune surveillance in vivo are suggested to better understand the pharmacological action of this drug.

\section{MATERIALS AND METHODS}

\section{Materials}

Celecoxib, etoricoxib, valdecoxib, aprotinin, calceinAM, luminol, orthovanadate and phenylmethylsulfonyl fluoride (PMSF) were purchased from Sigma-Aldrich (Taufkirchen, Germany). Rofecoxib was obtained from Enzo Life Sciences (Lörrach, Germany). Leupeptin was bought from Biomol (Hamburg, Germany). Dimethyl sulfoxide (DMSO), ethylenediaminetetraacetic acid (EDTA), glycerol, hydrogen peroxide $\left(\mathrm{H}_{2} \mathrm{O}_{2}\right)$, sodium chloride $(\mathrm{NaCl})$, Tris hydrocloride (Tris- $\mathrm{HCl})$, Tris ultrapure, calcium chloride dihydrate and magnesium chloride hexahydrate were obtained from AppliChem (Darmstadt, Germany). Dulbecco's modified Eagle's medium (DMEM) with $4.5 \mathrm{~g} / 1$ glucose and with $4 \mathrm{mM}$ L-glutamine and Roswell Park Memorial Institute medium (RPMI 1640) with L-glutamine were provided by Lonza (Cologne, Germany). FCS and penicillinstreptomycin were purchased from Invitrogen (Darmstadt, 
Germany) and phosphate-buffered saline (PBS) was provided by PAN Biotech (Aidenbach, Germany). Lymphocyte Separation Medium LSM 1077 was obtained from PromoCell (Heidelberg, Germany) and recombinant human interleukin-2 (IL-2) was supplied by ReliaTech (Wolfenbüttel, Germany). Triton ${ }^{\circledR}$ X-100 and paraformaldehyde were bought from Roth (Karlsruhe, Germany). Neutralizing ICAM-1/CD54 antibody and isotype control antibody were purchased from R\&D Systems (Wiesbaden-Nordenstadt, Germany). LEAFTM Purified anti-human CD11a and LEAFTM Purified Mouse IgG1, $\kappa$ Isotype Control were supplied by BioLegend (London, UK). Alexa Fluor ${ }^{\circledR} 488$ conjugated F(ab')2-Goat anti-Mouse IgG $(\mathrm{H}+\mathrm{L})$ Secondary Antibody was obtained from Life Technologies (Darmstadt, Germany). Normal Goat Serum (NGS) (Nr. B11-035) and glutaraldehyde were bought from PAA Laboratories (Pasching, Austria) and Electron Microscopy Sciences (Hatfield PA, USA), respectively. Goat anti-Mouse $\operatorname{IgG}(\mathrm{H} \& \mathrm{~L}) 15 \mathrm{~nm}$ gold antibody (Nr. EMGMHL 15) and fish gelatin (Nr. GEL 10) were provided by BBI Solutions (Cardiff, UK).

\section{Cell culture}

The NSCLC cell lines A549 and H460, the lung cancer patient's metastatic cells as well as the human bronchial epithelial cell line BEAS-2B (ATCCLGC, Wesel, Germany) were maintained in DMEM supplemented with $10 \%$ heat-inactivated FCS, $100 \mathrm{U} / \mathrm{ml}$ penicillin and $100 \mu \mathrm{g} / \mathrm{ml}$ streptomycin. A549 human lung carcinoma cells were purchased from DSMZ (Braunschweig, Germany; A549: DSMZ no.: ACC 107, species confirmation as human with IEF of $\mathrm{MDH}, \mathrm{NP}$; fingerprint: multiplex PCR of minisatellite markers revealed a unique DNA profile). H460 cells were purchased from ATCC-LGC (Wesel, Germany; ATCC ${ }^{\text {тм }}$ Number: HTB-177тм; cell line confirmation by cytogenetic analysis). Following resuscitation of frozen cultures none of the cell lines was cultured longer than 6 months.

Lung cancer patient's metastatic cells were obtained from resection of brain metastasis of a 47-year-old female Caucasian with NSCLC with the procedure of cell preparation described recently [52]. The patient had been informed about the establishment of cellular models from its tumor and had given informed consent in written form. The procedure was approved by the institutional ethical committee. Experiments were performed using passages 2-15 of these cells.

Cells were grown in a humidified incubator at $37^{\circ} \mathrm{C}$ and $5 \% \mathrm{CO}_{2}$. All incubations with test substances were performed in serum-free medium. PBS was used as vehicle for COX-2 inhibitors with a final concentration of $0.1 \%(\mathrm{v} / \mathrm{v})$ DMSO. As vehicle control PBS containing $0.1 \%$ (v/v) DMSO was used. The neutralizing ICAM-1/ CD54 antibody and the isotype control antibody were dissolved in PBS. The LEAFTM Purified anti-human
CD11a and LEAFTM Purified Mouse IgG1, $\kappa$ Isotype Control antibody were supplied soluted in $0.2 \mu \mathrm{m}$ filtered PBS ( $\mathrm{pH} 7.2$ ), containing no preservative and an endotoxin level $<0.01 \mathrm{ng} / \mu \mathrm{g}$ of the protein. For further dilutions PBS was used. For all antibody approaches PBS was used as vehicle control.

\section{Generation of LAK cells}

Peripheral blood mononuclear cells (PBMCs) were isolated from buffy coats of healthy donors. A volume of $50-70 \mathrm{ml}$ of each buffy coat was diluted 1:2 with PBS, carefully poured over $20 \mathrm{ml}$ of Lymphocyte Separation Medium (LSM 1077) and centrifuged at $1171 \times \mathrm{g}$ for 25 min; no brake was applied during deceleration. Following centrifugation lymphocytes concentrating in the interphase (white phase) were collected and washed twice with PBS. Washing was performed by centrifugation at $300 \times \mathrm{g}$ for $10 \mathrm{~min}$ in the first step and $200 \times \mathrm{g}$ for $10 \mathrm{~min}$ in the second step. After centrifugation pellets were resuspended in RPMI 1640 supplemented with 10\% heat-inactivated FCS, $100 \mathrm{U} / \mathrm{ml}$ penicillin and $100 \mathrm{mg} / \mathrm{ml}$ streptomycin. Adherent cells were removed from PBMC suspensions $\left(2 \times 10^{6}\right.$ cells $\left./ \mathrm{ml}\right)$ by attachment to plastic at the flask bottom for $1-2 \mathrm{~h}$. This procedure was repeated once more before cells in the culture supernatant were subjected to further treatment. For generation of LAK cells the cell suspension was incubated with $10 \mathrm{ng} / \mathrm{ml} \mathrm{IL-2}$ for 6 days at a density of about $1.5 \times 10^{6}$ cells $/ \mathrm{ml}$. After 3 days the medium was changed and fresh IL-2 was added.

For some experiments fractions of LAK cells were treated with vehicle or celecoxib. In this case vehicle or celecoxib was added to LAK cell suspension into the culture flask $48 \mathrm{~h}$ before starting the LAK cell cytotoxicity assay.

\section{LAK cell cytotoxicity assay}

The cytotoxicity of LAK cells on tumor or BEAS-2B cells was determined by the calcein-AM release assay. Tumor or BEAS-2B cells (target cells) were seeded into 96-well flat bottom plates at a density of $1 \times 10^{4}$ cells/well and were allowed to grow for $24 \mathrm{~h}$. Cells were washed with PBS and treated with vehicle or test substance in serumfree DMEM. Following a 48-h incubation period, target cells were washed and labeled with $5 \mu \mathrm{M}$ calcein-AM for 30 min. Subsequently, cells were washed with PBS and generated LAK cells (effector cells) were added to target cells at an effector:target cell ratio of $4: 1$ in a final volume of $100 \mu \mathrm{l} /$ well. After a 6 -h incubation $\left(37^{\circ} \mathrm{C}, 5 \% \mathrm{CO}_{2}\right)$ supernatants were transferred to other wells of the 96-well plate and remaining target cells were lysed with $2 \%(\mathrm{v} / \mathrm{v})$ Triton $^{\circledR}$ X-100. The fluorescence of supernatants and lysed target cells was recorded using a $485 \mathrm{~nm}$ excitation filter and a $535 \mathrm{~nm}$ emission filter by a Tecan infinite pro200 plate reader. LAK cell-induced cytotoxicity was monitored by the release of calcein by cancer cells into the supernatant due 
to toxic effects induced by LAK cells in the co-culture. To account for a probable modulation of cancer cell viability by vehicle or test substances, the fluorescence of cancer cells in the absence of effector cells, referred to as spontaneous release of calcein, was subtracted from these values. Finally, values were normalised to the release of calcein that can be achieved maximally by the effector cells. The percentage of LAK cytotoxicity was calculated as follows: \% LAK cytotoxicity $=$ (fluorescence of supernatant of sample well with effector cells - fluorescence of spontaneous release) / (fluorescence of maximal release - fluorescence of spontaneous release) [18]. Blank values were subtracted from the experimental data. Before LAK cytotoxicity was calculated the raw data of the fluorescent measurement were analysed with Nalimov test and outliers were excluded. In parallel to the LAK cell cytotoxicity assay viability of tumor cells was determined under equal conditions using the WST-1 assay (Roche, Grenzach-Wyhlen, Germany).

Experiments to determine the functional involvement of ICAM-1 in enhanced LAK cell-mediated tumor cell killing were performed using a neutralizing antibody against ICAM-1. Experiments with the ICAM-1 neutralizing antibody were performed by incubation of target cells with $1 \mu \mathrm{g} / \mathrm{ml}$ of an ICAM-1 antibody or an isotype control antibody as negative control for $2 \mathrm{~h}$. Following preincubation of cancer cells with the antibodies, supernatants were removed carefully and without washing the co-incubation with LAK cells was started. For analysis of the involvement of LFA-1 in LAK cell-mediated tumor cell lysis a CD11a antibody or an isotype control antibody was used. Experiments were carried out by incubation of LAK cells with $1 \mu \mathrm{g} / \mathrm{ml}$ of the respective antibody for $2 \mathrm{~h}$ before starting cytotoxicity assay by adding the LAK cell suspension with the therein containing antibody to the target cells.

\section{Quantitative RT-PCR analysis}

Lung cancer cells were seeded into 24-well plates at a density of $1 \times 10^{5}$ cells/well and allowed to grow for $24 \mathrm{~h}$. Following incubation of cells with celecoxib or its vehicle for the indicated times, cell culture media were removed and cells were lysed for subsequent RNA isolation. Total RNA was isolated using the RNeasy total RNA Kit (Qiagen, Hilden, Germany). $\beta$-Actin- (internal standard) and ICAM-1 mRNA levels were determined by quantitative real-time RT-PCR using the TaqMan ${ }^{\circledR}$ RNA-to- $\mathrm{C}_{\mathrm{T}}{ }^{\mathrm{TM}}$ Kit (Applied Biosystems, Darmstadt, Germany) according to the manufacturer's instruction. Primers and probe for human $\beta$-actin and ICAM-1 were Gene Expression Assay ${ }^{\mathrm{TM}}$ products (Applied Biosystems, Darmstadt, Germany).

\section{Western blot analysis}

To analyze protein levels of ICAM-1, lung tumor or non-tumor cells were grown in 6-well plates at a density of $2 \times 10^{5}$ cells/well for $24 \mathrm{~h}$ and subsequently incubated with vehicle or test substance for $48 \mathrm{~h}$. After incubation cells were washed with PBS, harvested and lysed in solubilization buffer (50 mM HEPES, $150 \mathrm{mM}$ $\mathrm{NaCl}, 1 \mathrm{mM}$ EDTA, 1\% (v/v) Triton ${ }^{\circledR} \mathrm{X}-100,10 \%$ (v/v) glycerol, $1 \mathrm{mM}$ PMSF, $1 \mathrm{mM}$ orthovanadate, $1 \mathrm{mg} / \mathrm{ml}$ leupeptin, $10 \mathrm{mg} / \mathrm{ml}$ aprotinin). Lysis was performed for at least $30 \mathrm{~min}$ on ice and frequently mixing on a vortex mixer. Subsequently, lysates were centrifuged at $10,000 \times \mathrm{g}$ for $5 \mathrm{~min}$ and supernatants were then used for Western blot analysis. Total protein of cell lysates was determined using the bicinchoninic acid assay (Pierce, Rockford, USA). Proteins were separated using 10\% sodium dodecyl sulfate (SDS) polyacrylamide gels and then transferred to nitrocellulose membranes (Roth, Karlsruhe, Germany) that were blocked with 5\% milk powder (BioRad, Munich, Germany). Membranes were incubated with a primary mouse monoclonal antibody raised to ICAM-1 (Santa Cruz Biotechnology, Heidelberg, Germany) at $4{ }^{\circ} \mathrm{C}$ overnight. Subsequently, blots were probed with horseradish peroxidase-conjugated antimouse IgG (New England Biolabs GmbH, Frankfurt am Main, Germany) and incubated for $1 \mathrm{~h}$ at room temperature. Antibody binding was visualized by a chemiluminiferous solution (100 mM Tris- $\mathrm{HCl} \mathrm{pH} 8.5$, $1.25 \mathrm{mM}$ luminol, $200 \mathrm{mM}$ p-coumaric acid, $0.09 \%$ [v/v] $\mathrm{H}_{2} \mathrm{O}_{2}, 0.0072 \%$ [v/v] DMSO). Densitometric analysis of band intensities was achieved by optical scanning and quantifying using the Quantity One 1-D Analysis Software (Bio-Rad, Munich, Germany). To identify the band size of the Western blots, the prestained SDS-PAGE Standard (Broad Range; Bio-Rad, Munich, Germany) was used. A regression of the prestained standard revealed a band size of ICAM- 1 at $90 \mathrm{kDa}$ and of $\beta$-actin at $42 \mathrm{kDa}$. Vehicle controls were defined as $100 \%$ for evaluation of changes in protein expression. To ascertain equal protein loading in Western blots of cell lysates, membranes were probed with an antibody raised to $\beta$-actin (SigmaAldrich). All densitometric values were normalized to $\beta$-actin.

\section{Analysis of CD11a with fluorescence microscopy}

For imaging of CD11a A549 cells were seeded at a density of $1-1.5 \times 10^{5}$ cells $/ \mathrm{ml}$ in 4 -well culture slides (BD Falcon $^{\mathrm{TM}}$, Heidelberg, Germany). After 3 days tumor cells were incubated with LAK cells at an effector:target cell ratio of $4: 1$ for $3 \mathrm{~h}$. Subsequently, cells were fixed with 4\% paraformaldehyde overnight, washed with PBS and blocked with PBS containing $0.3 \%(\mathrm{v} / \mathrm{v})$ Triton ${ }^{\circledR} \mathrm{X}-100$ and $5 \%(\mathrm{v} / \mathrm{v}) \mathrm{FCS}$ for $1 \mathrm{~h}$. After washing with PBS, cells were incubated with a CD11a antibody $(1: 250)$ for $1 \mathrm{~h}$. For this purpose the same antibody as in the LAK cell cytotoxicity assay was used. As secondary antibody a goat anti-mouse Alexa Fluor ${ }^{\circledR}$ 488-labeled IgG (1:1000) was used and incubation took place for $1 \mathrm{~h}$ as well. All 
antibodies were diluted in PBS containing $0.3 \%(\mathrm{v} / \mathrm{v})$ Triton $^{\circledR}$ X-100 and $1 \%(v / v)$ FCS. Notably, experiments with secondary antibody were performed in the dark.

\section{Electron microscopy}

The NSCLC cell line A549 was seeded on Melinex ${ }^{\circledR}$ films (Plano, Wetzlar, Germany) at a density of $5 \times 10^{5}$ cells per well in a 24 -well plate. After tumor cells were co-cultured with LAK cells (effector:target cell ratio of 4:1) for $3 \mathrm{~h}$, cells were carefully washed with PBS containing magnesium and calcium (each at $1 \mathrm{mM}$ ). Afterwards, cells were fixed with $4 \%$ paraformaldehyde containing magnesium and calcium (each at $1 \mathrm{mM}$ ) overnight. Subsequently, cells were blocked with $5 \%(\mathrm{v} / \mathrm{v})$ NGS in PBS for 30 min and incubated with the primary CD11a (LFA-1) antibody (1:250) diluted in PBS containing $5 \%(\mathrm{v} / \mathrm{v})$ NGS. For this purpose the same antibody as in the LAK cell cytotoxicity assay was used. After $1 \mathrm{~h}$ of incubation cells were washed with PBS containing $0.1 \%$ (v/v) Tween ${ }^{\circledR} 20$ before secondary goat anti-mouse antibody $15 \mathrm{~nm}$ gold (1:50) diluted in PBS containing 5\% (v/v) NGS, $0.1 \%(\mathrm{v} / \mathrm{v})$ Tween $^{\circledR} 20$ and $0.1 \%(\mathrm{v} / \mathrm{v})$ fish skin gelatin was added for $1 \mathrm{~h}$. Cells were washed with PBS containing 5\% (v/v) NGS, $0.1 \%(\mathrm{v} / \mathrm{v})$ Tween ${ }^{\circledR} 20$ and $0.1 \%(\mathrm{v} / \mathrm{v})$ fish skin gelatin and post-fixed with $2.5 \%(\mathrm{v} / \mathrm{v})$ glutaraldehyde.

For scanning electron microscopy, the film supports with the attached cells were washed with $0.1 \mathrm{M}$ sodium phosphate buffer $\mathrm{pH} 7.3$ and were subsequently dehydrated in a graded series of acetone. Critical point drying was performed in an Emitech K850 critical point dryer (Emitech Ltd. Ashford, UK) after three rounds of immersion in $\mathrm{CO}_{2}$. The dried film supports were mounted on scanning electron microscopy stubs with adhesive carbon tape (Plano, Wetzlar, Germany) and coated with a carbon layer using a Leica SCD500 coater (Leica Microsystems, Wetzlar, Germany). Specimens were viewed in a Merlin VP compact scanning electron microscope (Carl Zeiss Microscopy, Jena, Germany) operated at $5 \mathrm{kV}$. Images with a size of $1024 \times 768$ and $2048 \times 1536$ pixels were recorded with the SmartSEM Software (Carl Zeiss Microscopy) and were processed with Adobe Photoshop CS6 (Adobe Inc. San Jose, CA, USA).

\section{Statistical analysis}

Comparisons between groups were performed with Student's two-tailed $t$ test or with one-way ANOVA plus post hoc Bonferroni or Dunnett test using GraphPad Prism 5.0 (GraphPad Software, Inc., San Diego, USA).

\section{ACKNOWLEDGMENTS AND FUNDING}

The authors are grateful to Prof. Dr. V. Kiefel and his associates of the Institute of Transfusion Medicine, Rostock University Medical Center, for providing the buffy coats.
This study was supported by the FORUN programme (Rostock University Medical Center).

\section{CONFLICTS OF INTEREST}

The authors indicate no potential conflicts of interest.

\section{Abbreviations}

COX, cyclooxygenase; ICAM-1, intercellular adhesion molecule 1; IL-2, interleukin-2; LAK cells, lymphokineactivated killer cells; LFA-1, lymphocyte function associated antigen 1; NSCLC, non-small cell lung cancer.

\section{REFERENCES}

1. McAdam BF, Catella-Lawson F, Mardini IA, Kapoor S, Lawson JA, FitzGerald GA. Systemic biosynthesis of prostacyclin by cyclooxygenase (COX)-2: the human pharmacology of a selective inhibitor of COX-2. Proc Natl Acad Sci USA. 1999; 96:272-277.

2. Steinbach G, Lynch PM, Phillips RK, Wallace MH, Hawk E, Gordon GB, Wakabayashi N, Saunders B, Shen Y, Fujimura T, Su LK, Levin B, Godio L, et al. The effect of celecoxib, a cyclooxygenase-2 inhibitor, in familial adenomatous polyposis. N Engl J Med. 2000; 342:1946-1952.

3. Edelman MJ, Watson D, Wang X, Morrison C, Kratzke RA, Jewell S, Hodgson L, Mauer AM, Gajra A, Masters GA, Bedor M, Vokes EE, Green MJ. Eicosanoid modulation in advanced lung cancer: cyclooxygenase-2 expression is a positive predictive factor for celecoxib + chemotherapy Cancer and Leukemia Group B Trial 30203. J Clin Oncol. 2008; 26:848-855.

4. Wang Z, Duan J, Guo Q, Wei Z, Xue W, Wu M, Zhao J, Yang L, An T, Liu X, Wang J. A phase II clinical trial of celecoxib combined with platinum-based chemotherapy in the treatment of patients with advanced NSCLC as first-line treatment. Zhongguo Fei Ai Za Zhi. 2008; 11:425-430.

5. Kim ES, Hong WK, Lee JJ, Mao L, Morice RC, Liu DD, Jimenez CA, Eapen GA, Lotan R, Tang X, Newman RA, Wistuba II, Kurie JM. Biological activity of celecoxib in the bronchial epithelium of current and former smokers. Cancer Prev Res (Phila). 2011; 3:148-159.

6. Mao JT, Roth MD, Fishbein MC, Aberle DR, Zhang ZF, Rao JY, Tashkin DP, Goodglick L, Holmes EC, Cameron RB, Dubinett SM, Elashoff R, Szabo E, et al. Lung cancer chemoprevention with celecoxib in former smokers. Cancer Prev Res (Phila). 2011; 4:984-993.

7. Altorki NK, Keresztes RS, Port JL, Libby DM, Korst RJ, Flieder DB, Ferrara CA, Yankelevitz DF, Subbaramaiah K, Pasmantier MW, Dannenberg AJ. Celecoxib, a selective cyclo-oxygenase-2 inhibitor, enhances the response to preoperative paclitaxel and carboplatin in early-stage non-small-cell lung cancer. J Clin Oncol. 2003; 21:2645-2650. 
8. Ferlay J, Shin HR, Bray F, Forman D, Mathers C, Parkin DM. Estimates of worldwide burden of cancer in 2008: GLOBOCAN 2008. Int J Cancer. 2010; 127:2893-2917.

9. Grösch S, Maier TJ, Schiffmann S, Geisslinger G. Cyclooxygenase-2 (COX-2)-independent anticarcinogenic effects of selective COX-2 inhibitors. J Natl Cancer Inst. 2006; 98:736-747.

10. Zhang X, Morham SG, Langenbach R, Young DA. Malignant transformation and antineoplastic actions of nonsteroidal antiinflammatory drugs (NSAIDs) on cyclooxygenase-null embryo fibroblasts. J Exp Med. 1999; 190:451-459.

11. Grösch S, Tegeder I, Niederberger E, Bräutigam L, Geisslinger G. COX-2 independent induction of cell cycle arrest and apoptosis in colon cancer cells by the selective COX-2 inhibitor celecoxib. FASEB J. 2001; $15: 2742-2744$.

12. Hwang DH, Fung V, Dannenberg AJ. National Cancer Institute workshop on chemopreventive properties of nonsteroidal anti-inflammatory drugs: role of COX-dependent and -independent mechanisms. Neoplasia. 2002; 4:91-97.

13. Denkert C, Fürstenberg A, Daniel PT, Koch I, Köbel M, Weichert W, Siegert A, Hauptmann S. Induction of G0/G1 cell cycle arrest in ovarian carcinoma cells by the antiinflammatory drug NS-398, but not by COX-2-specific RNA interference. Oncogene. 2003; 22:8653-8661.

14. Ramer R, Walther U, Borchert P, Laufer S, Linnebacher M, Hinz B. Induction but not inhibition of COX-2 confers human lung cancer cell apoptosis by celecoxib. J Lipid Res. 2013; 54:3116-3129.

15. Kundu N, Walser TC, Ma X, Fulton AM. Cyclooxygenase inhibitors modulate NK activities that control metastatic disease. Cancer Immunol Immunother. 2005; 54:981-987.

16. Bella J, Kolatkar PR, Marlor CW, Greve JM, Rossmann MG. The structure of the two amino-terminal domains of human ICAM-1 suggests how it functions as a rhinovirus receptor and as an LFA-1 integrin ligand. Proc Natl Acad Sci USA. 1998; 95:4140-4145.

17. Beal AM, Anikeeva N, Varma R, Cameron TO, Norris PJ, Dustin ML, Sykulev Y. Protein kinase C $\theta$ regulates stability of the peripheral adhesion ring junction and contributes to the sensitivity of target cell lysis by CTL. J Immunol. 2008; 181:4815-4824.

18. Vánky F, Wang P, Patarroyo M, Klein E. Expression of the adhesion molecule ICAM-1 and major histocompatibility complex class I antigens on human tumor cells is required for their interaction with autologous lymphocytes in vitro. Cancer Immunol Immunother. 1990; 31:19-27.

19. Naganuma H, Kiessling R, Patarroyo M, Hansson M, Handgretinger R, Grönberg A. Increased susceptibility of IFN- $\gamma$-treated neuroblastoma cells to lysis by lymphokineactivated killer cells: participation of ICAM-1 induction on target cells. Int J Cancer. 1991; 47:527-532.

20. Webb DS, Mostowski HS, Gerrard TL. Cytokine-induced enhancement of ICAM-1 expression results in increased vulnerability of tumor cells to monocyte-mediated lysis. J Immunol. 1991; 146:3682-3686.

21. Altomonte M, Gloghini A, Bertola G, Gasparollo A, Carbone A, Ferrone S, Maio M. Differential expression of cell adhesion molecules CD54/CD11a and CD58/CD2 by human melanoma cells and functional role in their interaction with cytotoxic cells. Cancer Res. 1993; 53:3343-3348.

22. Melis M, Spatafora M, Melodia A, Pace E, Gjomarkaj M, Merendino AM, Bonsignore G. ICAM-1 expression by lung cancer cell lines: effects of upregulation by cytokines on the interaction with LAK cells. Eur Respir J. 1996; 9:1831-1838.

23. Wang R, Jaw JJ, Stutzman NC, Zou Z, Sun PD. Natural killer cell-produced IFN- $\gamma$ and TNF- $\alpha$ induce target cell cytolysis through up-regulation of ICAM-1. J Leukoc Biol. 2012; 91:299-309.

24. Sunami T, Yashiro M, Chung KH. ICAM-1 (intercellular adhesion molecule-1) gene transfection inhibits lymph node metastasis by human gastric cancer cells. Jpn J Cancer Res. 2000; 91:925-933.

25. Tachimori A, Yamada N, Sakate Y, Yashiro M, Maeda K, Ohira M, Nishino H, Hirakawa K. Up regulation of ICAM-1 gene expression inhibits tumour growth and liver metastasis in colorectal carcinoma. Eur J Cancer. 2005; 41:1802-1810.

26. Haustein M, Ramer R, Linnebacher M, Manda K, Hinz B. Cannabinoids increase lung cancer cell lysis by lymphokine-activated killer cells via upregulation of ICAM-1. Biochem Pharmacol. 2014; 92:312-325.

27. Ogawa Y, Hirakawa K, Nakata B, Fujihara T, Sawada T, Kato Y, Yoshikawa K, Sowa M. Expression of intercellular adhesion molecule-1 in invasive breast cancer reflects low growth potential, negative lymph node involvement, and good prognosis. Clin Cancer Res. 1998; 4:31-36.

28. Fujihara $\mathrm{T}$, Yashiro $M$, Inoue $\mathrm{T}$, Sawada $\mathrm{T}$, Kato $\mathrm{Y}$, Ohira M, Nishiguchi Y, Ishikawa T, Sowa M, Chung KH. Decrease in ICAM-1 expression on gastric cancer cells is correlated with lymph node metastasis. Gastric Cancer. 1999; 2:221-225.

29. Maeda K, Kang SM, Sawada T, Nishiguchi Y, Yashiro M, Ogawa Y, Ohira M, Ishikawa T, Hirakawa-YS Chung K. Expression of intercellular adhesion molecule-1 and prognosis in colorectal cancer. Oncol Rep. 2002; 9:511-514.

30. Grimm EA, Mazumder A, Zhang HZ, Rosenberg SA. Lymphokine-activated killer cell phenomenon. Lysis of natural killer-resistant fresh solid tumor cells by interleukin 2-activated autologous human peripheral blood lymphocytes. J Exp Med. 1982; 155:1823-1841.

31. Marlin SD, Springer TA. Purified intercellular adhesion molecule-1 (ICAM-1) is a ligand for lymphocyte function-associated antigen-1 (LFA-1). Cell. 1987; 51:813-819.

32. Textor S, Accardi R, Havlova T, Hussain I, Sylla BS,

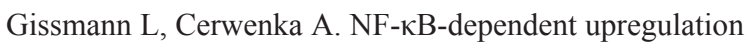
of ICAM-1 by HPV16-E6/E7 facilitates NK cell/target cell interaction. Int J Cancer. 2011; 128:1104-1113. 
33. Chen X, Trivedi PP, Ge B, Krzewski K, Strominger JL. Many NK cell receptors activate ERK2 and JNK1 to trigger microtubule organizing center and granule polarization and cytotoxicity. Proc Natl Acad Sci USA. 2007; 104:6329-6334.

34. Kusunoki N, Yamazaki R, Kawai S. Induction of apoptosis in rheumatoid synovial fibroblasts by celecoxib, but not by other selective cyclooxygenase 2 inhibitors. Arthritis Rheum. 2002; 46:3159-3167.

35. Schiffmann S, Maier TJ, Wobst I, Janssen A, CorbanWilhelm H, Angioni C, Geisslinger G, Grösch S. The antiproliferative potency of celecoxib is not a class effect of coxibs. Biochem Pharmacol. 2008; 76:179-187.

36. Maier TJ, Schiffmann S, Wobst I, Birod K, Angioni C, Hoffmann M, Lopez JJ, Glaubitz C, Steinhilber D, Geisslinger G, Grösch S. Cellular membranes function as a storage compartment for celecoxib. J Mol Med (Berl). 2009; 87:981-993.

37. Niederberger E, Tegeder I, Vetter G, Schmidtko A, Schmidt H, Euchenhofer C, Bräutigam L, Grösch S, Geisslinger G. Celecoxib loses its anti-inflammatory efficacy at high doses through activation of NF-kappaB. FASEB J. 2001; 15:1622-1624.

38. Kim SH, Song SH, Kim SG, Chun KS, Lim SY, Na HK, Kim JW, Surh YJ, Bang YJ, Song YS. Celecoxib induces apoptosis in cervical cancer cells independent of cyclooxygenase using NF-kappaB as a possible target. J Cancer Res Clin Oncol. 2004; 130:551-560.

39. Sakurada S, Kato T, Okamoto T. Induction of cytokines and ICAM-1 by proinflammatory cytokines in primary rheumatoid synovial fibroblasts and inhibition by N-acetylL-cysteine and aspirin. Int Immunol. 1996; 8:1483-1493.

40. Liu WM, Joel SP. The schedule-dependent effects of etoposide in leukaemic cell lines: a function of concentration and duration. Cancer Chemother Pharmacol. 2003; 51:291-296.

41. Beck-Schimmer B, Madjdpour C, Kneller S, Ziegler U, Pasch T, Wüthrich RP, Ward PA, Schimmer RC. Role of alveolar epithelial ICAM-1 in lipopolysaccharide-induced lung inflammation. Eur Respir J. 2002; 19:1142-1150.

42. Reddel RR, Ke Y, Gerwin BI, McMenamin MG, Lechner JF, Su RT, Brash DE, Park JB, Rhim JS, Harris CC. Transformation of human bronchial epithelial cells by infection with SV40 or adenovirus-12 SV40 hybrid virus, or transfection via strontium phosphate coprecipitation with a plasmid containing SV40 early region genes. Cancer Res. 1988; 48:1904-1909.

43. Williams CS, Watson AJ, Sheng H, Helou R, Shao J, DuBois RN. Celecoxib prevents tumor growth in vivo without toxicity to normal gut: lack of correlation between in vitro and in vivo models. Cancer Res. 2000; 60:6045-6051.

44. Gallicchio M, Rosa AC, Dianzani C, Brucato L, Benetti E, Collino M, Fantozzi R. Celecoxib decreases expression of the adhesion molecules ICAM-1 and VCAM-1 in a colon cancer cell line (HT29). Br J Pharmacol. 2008; 153:870-878.
45. Dianzani C, Brucato L, Gallicchio M, Rosa AC, Collino M, Fantozzi R. Celecoxib modulates adhesion of HT29 colon cancer cells to vascular endothelial cells by inhibiting ICAM-1 and VCAM-1 expression. Br J Pharmacol. 2008; 153:1153-1161.

46. Jacob S, Laury-Kleintop L, Lanza-Jacoby S. The select cyclooxygenase- 2 inhibitor celecoxib reduced the extent of atherosclerosis in apo E-/- mice. J Surg Res. 2008; 146:135-142.

47. Miyamoto K, Miyake S, Mizuno M, Oka N, Kusunoki S, Yamamura T. Selective COX-2 inhibitor celecoxib prevents experimental autoimmune encephalomyelitis through COX2-independent pathway. Brain. 2006; 129:1984-1992.

48. Cuzzocrea S, Mazzon E, Serraino I, Dugo L, Centorrino T, Ciccolo A, Sautebin L, Caputi AP. Celecoxib, a selective cyclo-oxygenase- 2 inhibitor reduces the severity of experimental colitis induced by dinitrobenzene sulfonic acid in rats. Eur J Pharmacol. 2001; 431:91-102.

49. Cuzzocrea S, Mazzon E, Sautebin L, Dugo L, Serraino I, De Sarro A, Caputi AP. Protective effects of Celecoxib on lung injury and red blood cells modification induced by carrageenan in the rat. Biochem Pharmacol. 2002; 63:785-795.

50. Yamada M, Yanaba K, Hasegawa M, Matsushita Y, Horikawa M, Komura K, Matsushita T, Kawasuji A, Fujita T, Takehara K, Steeber DA, Tedder TF, Sato S. Regulation of local and metastatic host-mediated antitumour mechanisms by L-selectin and intercellular adhesion molecule-1. Clin Exp Immunol. 2006; 143:216-227.

51. Schmits R, Kündig TM, Baker DM, Shumaker G, Simard JJ, Duncan G, Wakeham A, Shahinian A, van der Heiden A, Bachmann MF, Ohashi PS, Mak TW, Hickstein DD. LFA-1-deficient mice show normal CTL responses to virus but fail to reject immunogenic tumor. J Exp Med. 1996; 183:1415-1426.

52. Ramer R, Bublitz K, Freimuth N, Merkord J, Rohde H, Haustein M, Borchert P, Schmuhl E, Linnebacher M, Hinz B. Cannabidiol inhibits lung cancer cell invasion and metastasis via intercellular adhesion molecule-1. FASEB J. 2012; 26:1535-1548.

53. Sartor WM, Kyprianou N, Fabian DF, Lefor AT. Enhanced expression of ICAM-1 in a murine fibrosarcoma reduces tumor growth rate. J Surg Res. 1995; 59:66-74.

54. Tomita Y, Nishiyama T, Watanabe H, Fujiwara M, Sato S. Expression of intercellular adhesion molecule-1 (ICAM-1) on renal-cell cancer: possible significance in host immune responses. Int J Cancer. 1990; 46:1001-1006.

55. Maurer CA, Friess H, Kretschmann B, Wildi S, Müller C, Graber H, Schilling M, Büchler MW. Over-expression of ICAM-1, VCAM-1 and ELAM-1 might influence tumor progression in colorectal cancer. Int J Cancer. 1998; 79:76-81.

56. Hosch SB, Meyer AJ, Schneider C, Stoecklein N, Prenzel KL, Pantel K, Broelsch CE, Izbicki JR. Expression and prognostic significance of HLA class I, ICAM-1, and tumor-infiltrating lymphocytes in esophageal cancer. J Gastrointest Surg. 1997; 1:316-323. 